\title{
The Effectiveness of Smart Kit in Enhancing Students' Mathematical Process Skills and Achievement in Mathematics
}

\author{
Zulkifley Mohamed, Rosmah Ramli, Abu Kassim Ali Musa, Nor Hashimah Abu Bakar, \\ Faiz Zulkifli
}

\begin{abstract}
The utilization of teaching aids is crucial in enhancing students' mathematical process skills. However, teachers give less accentuation on this aspect of usage which leads to students' low competence in mathematical process skills. The purpose of this study was to determine the effectiveness of a developed teaching aids, in particular, a Smart Kit in enhancing mathematical process skills and achievement among selected primary school students in Hulu Kinta, Perak. The experimental method was used in this study. Cluster sampling was used to select the samples. The samples were divided into two groups, the control and treatment groups which each consisted of 36 respondents. The treatment group was engaged with the developed Smart Kit while the students in the control group followed the conventional method of teaching and learning. Measurement and Geometry topics at primary school level were selected and students' mathematical process skills were assessed based on Malaysia Assessment and Curriculum Standard Documents. The findings revealed that there was a significant difference in problem solving, reasoning and connecting skills between the control group and the treatment group. Furthermore, the mathematical achievement of the treatment group was higher than the control group. In conclusion, the utilization of the developed Smart Kit enhanced students' problem solving, reasoning and connecting skills, and improved mathematical achievement. In implicative insinuation, the use of the developed Smart Kit can help teachers and students in teaching and learning processes specifically on the topics of Measurement and Geometry.
\end{abstract}

Index Terms - Mathematical process skills, mathematics achievement, Smart Kid, teaching aids.

\section{INTRODUCTION}

The primary goal of an educational system is to enhance students' understanding of the basic concepts learned. Therefore, effective teaching is vital as it requires a conducive environment in order to encourage students to think, question and solve problems [1]. Mathematics teaching and learning process give priority to the mastery of knowledge and understanding in enabling students to apply the concepts, principles and mathematical processes learned. The teaching method of a teacher is an important component in teaching and learning sessions.

Revised Manuscript Received on July 10, 2019

Zulkifley Mohamed, Department of Mathematics, Faculty of Science and Mathematics, Universiti Pendidikan Sultan Idris, 35900 Tanjong Malim, Perak, Malaysia.

Rosmah Ramli, Department of Mathematics, IPG Ipoh Campus, 31150 Hulu Kinta, Perak, Malaysia.

Abu Kassim Ali Musa, Department of Educational Technology, IPG Ipoh Campus, 31150 Hulu Kinta, Perak, Malaysia.

Nor Hashimah Abu Bakar, Department of Mathematics, IPG Ipoh Campus, 31150 Hulu Kinta, Perak, Malaysia.

Faiz Zulkifli, Faculty of Computer and Mathematical Sciences, Universiti Teknologi MARA, Perak Branch, Tapah Campus, 35400 Tapah Road, Perak, Malaysia.
Mathematical process skills can benefit the students which enable them to acquire and use mathematical knowledge and skills [2]. Mathematical process skills consists of problem solving, reasoning and proving, reflecting, selecting tools and computational strategies, connecting, representing, and communicating. The difficulties in the mathematical process skills are to communicate, to connect, to solve problems and to make representations [3]. Through mathematical process skills, students need to learn and apply each core skill to meet predetermined expectations in each learning standard. These mathematical process skills are interdependent with each other and to ascertain that the teacher covers all the basic skills, preparation and orchestrating ahead of time for classroom activities are very consequential. Creative teachers must be keenly intellective in making systematic planning and record all their edification activities [4]. Teachers who are competent and able to manage their classroom effectively will be able to teach creatively and impeccably [5]. The utilization of teaching aids (TAs) can have a positive effect on students' academic excellence and the teacher's own teaching method. There are many past studies that have been proven to show positive effects of TAs, such as studies by [3], [6]. Their findings showed that the utilization of TAs by teachers are able to make students fixate on the lesson during the teaching and learning (TaL) process. With the recent development in education, the Malaysia Ministry of Education has made the utilization of TAs as a paramount component in TaL in every school [7]. This is to ascertain TaL will be more intriguing as well as to enhance students understanding in the edification [8]. The utilization of TAs, in particular, the Smart Kit can avail in enhancing the students' facility to develop mathematical process skills.

\section{PROBLEM STATEMENT}

Mathematics is a subject that must be learned in all school levels. It is also a main requirement of tertiary level entrance for almost all majors in higher learning institutions [9]. It can also be difficult and bored to learn mathematics [10], as learning mathematics involves a lot of calculations and it requires continuous understanding and effort which 
causes perplexed and bored [11]. This problem led to a low level of mastery and achievement in mathematical subjects [12]. If this issue persists, it will affect the students' opportunity to pursue in higher education.

Knowledge of mathematics that combine each core of mathematical process skills needs to be mastered and practiced by all teachers so that $\mathrm{TaL}$ will be more meaningful. It is due to the fact that meaningful mathematical learning is essential to reinforce the mathematical foundations and concepts to be applied to higher education levels [13]. It is found that previous studies did not incorporate each core of mathematical process skills. In [14] examined students' perceptions on learning webbased mathematical problem solving with constructivist approaches, while in [15] examined the relationship between student, content and teaching style of teacher to develop a higher level of scientific reasoning skills.

The comprehension to each mathematical process skills cores enables the engenderment of students with affluent and consequential mathematical knowledge. Based on the 10th shift of the Malaysian Education Development Plan (MEDP 2013-2025), the government intends to maximize the students' success for every dollar spent. Students with meaningful mathematical thinking are among the expected learning outcomes in mathematics education [16]. However, what's transpiring nowadays is that students are learning mathematics only with the aim of passing and achieving excellent results in the examination [17]. This achievement without a thorough appreciation results in the students incapable to understand and apply the current and future mathematical knowledge [18]. TaL which accentuates on content knowledge and procedures will only engender mathematically competent students but fail to develop the resplendency implicatively insinuated in the way of thinking, practice and role as a member of society [19].

TAs is one of the paramount elements in the implementation of teaching and learning. TAs is the medium used by teachers in the form of objects, tools and materials to facilitate them in providing knowledge to students in their teaching. According to [3], the use of TAs can improve the quality of teaching and learning in the classroom. Many studies show that the efficacy of utilizing TAs can positively impact students' understanding of the subjects [20]. However, there are restrictions in the teacher's efforts to diversify the source of the material in enhancing TAs. This is evident by the study of [20]-[22]. All these studies revealed that teachers could not utilize TAs due to lack of resources in obtaining materials. Therefore, TAs in particular Smart Kit can be optional edifying avails to facilitate teachers in implementing TaL of mathematics. This study developed the Smart Kit for unit conversions in Measurement and Geometry topics. This Smart Kit is a coalescence of ten components of TAs that can be utilized in Year One to Year 6 of teaching mathematics.

\section{METHODOLOGY}

Experimental method was used in this study. Cluster random sampling was engaged in the selection of a sample.
The study samples consist of two groups of year five primary school in Chepor, Perak. The study samples were divided into two groups, namely the control and treatment groups. The students in the control group were taught using conventional methods while the Smart Kit was utilized in the treatment group. Each of the groups consisted of 36 students. Measurement and Geometry topics were selected in this study as there are three sub topics namely Length, Mass and Volume that requires the ability to solve equation and conversions of metrics unit. These topics were selected as to evaluate the students' problem solving, reasoning and connecting skills as part of mathematical process skills. The assessment instrument which was adapted from Malaysia Assessment and Curriculum Standard Documents was utilized in assessing students' mathematical process skills.

In assessing students' performance on Measurement and Geometry topics, both groups were undergone pre-test and post-test to determine the difference in their mean assessment score.

\section{RESULTS AND DISCUSSION}

\section{A. Mathematical Process Skills}

Table 1 shows the comparison of the frequency $(f)$ and percentage $(\%)$ of the level of attainment in problem solving skills among the control and treatment groups in their pretest and post-test. This assessment was made using the problem solving skills evaluation instrument adapted from Malaysia Assessment and Curriculum Standard Documents.

Table 1: Capability of problem solving skills in control $(n=36)$ and treatment $(n=36)$ groups for pre and post test

\begin{tabular}{|c|c|c|c|c|c|}
\hline \multirow[t]{3}{*}{$\begin{array}{c}\text { Attainment } \\
\text { Level }\end{array}$} & \multirow[t]{3}{*}{ Indicator } & \multicolumn{2}{|c|}{ Control Group } & \multicolumn{2}{|c|}{$\begin{array}{c}\text { Treatment } \\
\text { Group }\end{array}$} \\
\hline & & \multicolumn{2}{|c|}{$f$ and $(\%)$} & \multicolumn{2}{|c|}{$f$ and $(\%)$} \\
\hline & & Pre & Post & Pre & Post \\
\hline 1 & $\begin{array}{l}\text { Be able to } \\
\text { describe the } \\
\text { steps in } \\
\text { solving the } \\
\text { problems. }\end{array}$ & $\begin{array}{c}22 \\
(61.11)\end{array}$ & $\begin{array}{c}7 \\
(19.44)\end{array}$ & $\begin{array}{c}20 \\
(55.56)\end{array}$ & - \\
\hline 2 & $\begin{array}{l}\text { Be able to } \\
\text { solve routine } \\
\text { problems } \\
\text { with } \\
\text { guidance. }\end{array}$ & $\begin{array}{c}13 \\
(36.11)\end{array}$ & $\begin{array}{c}20 \\
(55.56)\end{array}$ & $\begin{array}{c}14 \\
(38.89)\end{array}$ & - \\
\hline 3 & $\begin{array}{l}\text { Be able to } \\
\text { solve routine } \\
\text { problems } \\
\text { involving } \\
\text { calculation } \\
\text { without } \\
\text { guidance. }\end{array}$ & $\begin{array}{c}1 \\
(2.78)\end{array}$ & $\begin{array}{c}6 \\
(16.67)\end{array}$ & $\begin{array}{c}2 \\
(5.55)\end{array}$ & $\begin{array}{c}12 \\
(33.33)\end{array}$ \\
\hline
\end{tabular}




\begin{tabular}{|c|c|c|c|c|c|}
\hline 4 & $\mid \begin{array}{l}\text { Be able to } \\
\text { solve more } \\
\text { complex } \\
\text { routine } \\
\text { problems. }\end{array}$ & - & $\begin{array}{c}3 \\
(8.33)\end{array}$ & - & $\begin{array}{c}11 \\
(30.56)\end{array}$ \\
\hline 5 & \begin{tabular}{|l} 
Be able to \\
solve more \\
complex \\
routine \\
problems \\
using \\
varieties of \\
strategies.
\end{tabular} & - & - & - & $\begin{array}{c}8 \\
(22.22)\end{array}$ \\
\hline 6 & $\begin{array}{l}\text { Be able to } \\
\text { solve non- } \\
\text { routine } \\
\text { problems } \\
\text { creatively } \\
\text { and } \\
\text { innovatively. }\end{array}$ & - & - & - & $\begin{array}{c}5 \\
(13.89)\end{array}$ \\
\hline
\end{tabular}

\section{Reasoning Skills}

Table 2 shows the comparisons of the frequency $(f)$ and percentage $(\%)$ of the level of attainment in reasoning skills among the control and treatment groups in their pre-test and post-test.

Table 2: Capability of reasoning skills in control $(n=36)$ and treatment $(n=36)$ groups for pre and post test

\begin{tabular}{|c|c|c|c|c|c|}
\hline \multirow[t]{3}{*}{$\begin{array}{c}\text { Attainmen } \\
\text { t Level }\end{array}$} & \multirow[t]{3}{*}{ Indicator } & \multicolumn{2}{|c|}{ Control Group } & \multicolumn{2}{|c|}{$\begin{array}{c}\text { Treatment } \\
\text { Group }\end{array}$} \\
\hline & & \multicolumn{2}{|c|}{$f$ and $(\%)$} & \multicolumn{2}{|c|}{$f$ and $(\%)$} \\
\hline & & Pre & Post & Pre & Post \\
\hline 1 & $\begin{array}{l}\text { Be able to justify } \\
\text { logically } \\
\text { mathematical } \\
\text { activities with } \\
\text { guidance }\end{array}$ & $\begin{array}{c}20 \\
(55.56)\end{array}$ & $\begin{array}{c}6 \\
(16.67)\end{array}$ & $\begin{array}{c}19 \\
(52.78)\end{array}$ & - \\
\hline 2 & $\begin{array}{l}\text { Be able to justify } \\
\text { logically } \\
\text { mathematical } \\
\text { activities without } \\
\text { guidance. }\end{array}$ & $\begin{array}{c}13 \\
(36.11)\end{array}$ & $\begin{array}{c}18 \\
(50.00)\end{array}$ & $\begin{array}{c}15 \\
(41.67)\end{array}$ & - \\
\hline 3 & $\begin{array}{l}\text { Be able to justify } \\
\text { logically } \\
\text { mathematical } \\
\text { activities without } \\
\text { guidance } \\
\text { involving } \\
\text { calculation }\end{array}$ & $\begin{array}{c}3 \\
(8.33)\end{array}$ & $\begin{array}{c}9 \\
(25.00)\end{array}$ & $\begin{array}{c}2 \\
(5.55)\end{array}$ & $\begin{array}{c}11 \\
(30.56)\end{array}$ \\
\hline 4 & $\begin{array}{l}\text { Be able to justify } \\
\text { logically } \\
\text { mathematical } \\
\text { activities without } \\
\text { guidance } \\
\text { involving more } \\
\text { than one } \\
\text { calculation. }\end{array}$ & - & $\begin{array}{c}3 \\
(8.33)\end{array}$ & - & $\begin{array}{c}14 \\
(38.89)\end{array}$ \\
\hline 5 & $\begin{array}{l}\text { Be able to justify } \\
\text { logically }\end{array}$ & - & - & - & $\begin{array}{c}8 \\
(22.22) \\
\end{array}$ \\
\hline
\end{tabular}

\begin{tabular}{|l|l|c|c|c|c|}
\hline & $\begin{array}{l}\text { mathematical } \\
\text { activities } \\
\text { involving routine } \\
\text { problem. }\end{array}$ & & & & \\
\hline 6 & $\begin{array}{l}\text { Be able to justify } \\
\text { logically } \\
\text { mathematical } \\
\text { activities } \\
\text { involving non- } \\
\text { routine, creative } \\
\text { and innovative } \\
\text { problem solving. }\end{array}$ & - & - & 3 \\
& & $(8.33)$ \\
\hline
\end{tabular}

\section{Connecting Skills}

Table 3 shows the comparisons of the frequency $(f)$ of the level of attainment in connecting skills among the control and treatment groups in their pre-test and post-test.

Table 3: Capability of connecting skills in control $(n=36)$ and treatment $(n=36)$ groups for pre and post test

\begin{tabular}{|c|c|c|c|c|c|}
\hline \multirow[t]{2}{*}{$\begin{array}{c}\text { Attainment } \\
\text { Level }\end{array}$} & \multirow[t]{2}{*}{ Indicator } & \multicolumn{2}{|c|}{$\begin{array}{c}\text { Control Group } \\
f \text { and }(\%) \\
\end{array}$} & \multicolumn{2}{|c|}{$\begin{array}{c}\text { Treatment Group } \\
f \text { and }(\%)\end{array}$} \\
\hline & & Pre & Post & Pre & Post \\
\hline 1 & 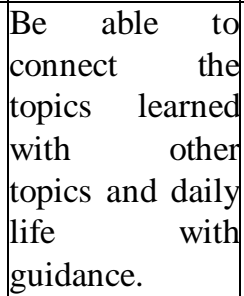 & $\begin{array}{c}19 \\
(52.78)\end{array}$ & $\begin{array}{c}10 \\
(27.78)\end{array}$ & $\begin{array}{c}21 \\
(58.33)\end{array}$ & - \\
\hline 2 & $\begin{array}{lr}\text { Be } & \text { able } \\
\text { connect } & \text { to } \\
\text { topics } & \text { learned } \\
\text { with } & \text { other } \\
\text { topics } & \text { and } \\
\text { life } & \text { daily } \\
\text { guidance. }\end{array}$ & $\begin{array}{c}15 \\
(41.67)\end{array}$ & $\begin{array}{c}20 \\
(55.56)\end{array}$ & $\begin{array}{c}12 \\
(33.33)\end{array}$ & $\begin{array}{c}5 \\
(13.89)\end{array}$ \\
\hline 3 & $\begin{array}{lr}\text { Be able } & \text { to } \\
\text { connect } & \text { the } \\
\text { concepts } & \text { and } \\
\text { procedures } & \text { to } \\
\text { solve } & \text { math } \\
\text { sentences } & \\
\text { problems } & \end{array}$ & $\begin{array}{c}2 \\
(5.55)\end{array}$ & $\begin{array}{c}4 \\
(11.11)\end{array}$ & $\begin{array}{c}2 \\
(5.56)\end{array}$ & $\begin{array}{c}8 \\
(22.22)\end{array}$ \\
\hline 4 & $\begin{array}{lr}\text { Be able } & \text { to } \\
\text { connect } & \text { the } \\
\text { concepts } & \text { and } \\
\text { procedures } & \text { to } \\
\text { solve routine } \\
\text { daily }\end{array}$ & - & $\begin{array}{c}2 \\
(5.55)\end{array}$ & $\begin{array}{c}1 \\
(2.78)\end{array}$ & $\begin{array}{c}14 \\
(38.89)\end{array}$ \\
\hline
\end{tabular}



AND ACHIEVEMENT IN MATHEMATICS

\begin{tabular}{|c|c|c|c|c|c|}
\hline 5 & $\begin{array}{|lr|}\text { Be able } & \text { to } \\
\text { connect } & \text { the } \\
\text { concepts r and } \\
\text { procedures ro to } \\
\text { solve routine } \\
\text { daily problems } \\
\text { by using various } \\
\text { strategies. }\end{array}$ & - & - & - & $\begin{array}{c}5 \\
(13.89)\end{array}$ \\
\hline 6 & \begin{tabular}{|lr} 
Be able & to \\
connect & the \\
concepts & and \\
procedures & to \\
solve & non- \\
routine & daily \\
problems & \\
creatively & and \\
innovatively.
\end{tabular} & - & - & - & $\begin{array}{c}4 \\
(11.11)\end{array}$ \\
\hline
\end{tabular}

\section{The Mathematical Process Skills Discussion}

The data analysis made in Table 1-3 showed the mastery of problem solving, reasoning and connecting skills for the control group only increased to level 4 after coveted instruction was carried out. On the other hand, the problem solving, reasoning and connecting skills for the treatment group using the Smart Kit are encouraging and demonstrating an increase up to level 6 .

The findings showed that the use of the Smart Kit can improve the problem solving, reasoning and connecting skills related to Measurement and Geometry topics. The findings are consistent with the findings of [23] that found the use of WebQuest Web-based applications can produce an effective learning environment. The use of the Smart Kit also strives for students to make sense of the idea, to create an idea concerning the problems to be solved and hence solved the problems according to the steps that had been learned. This finding is line with the findings of [24] which stated that constructivist learning is optically discerned to be the best ideas about how students learn and have a vigorous impact on their learning, especially in Mathematics.

\section{B. Student Mathematical Achievement Findings Mathematical Achievement of Control Group}

Fig. 1 shows the comparison of the achievement of the control in pre-test and post-test. A total of eight questions related to Measurement and Geometry topics was answered by the students. This comparison is based on the number of questions correctly answered.

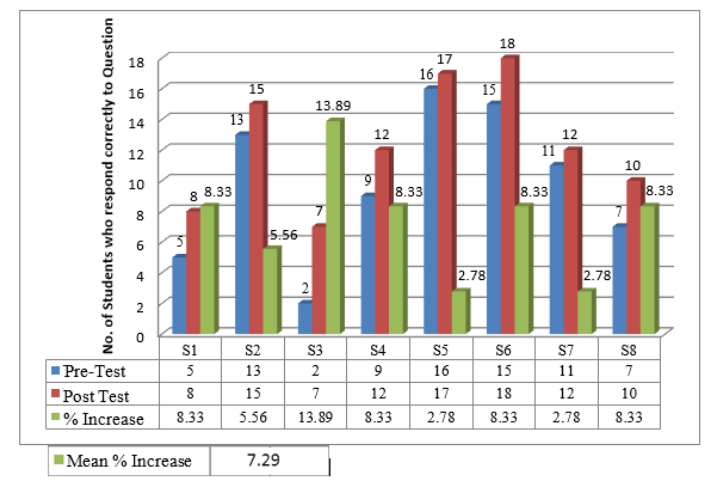

Fig. 1: Comparison of Control Group Achievement PreTest $(\mathrm{N}=36)$ and Post-Test $(\mathrm{N}=36)$

\section{Mathematical Achievement of the Treatment Group}

Fig. 2 shows the comparison of the achievement of the treatment group in pre-test and post-test. A total of eight questions related to Measurement and Geometry topics was answered by the students. This comparison is based on the number of questions correctly answered.

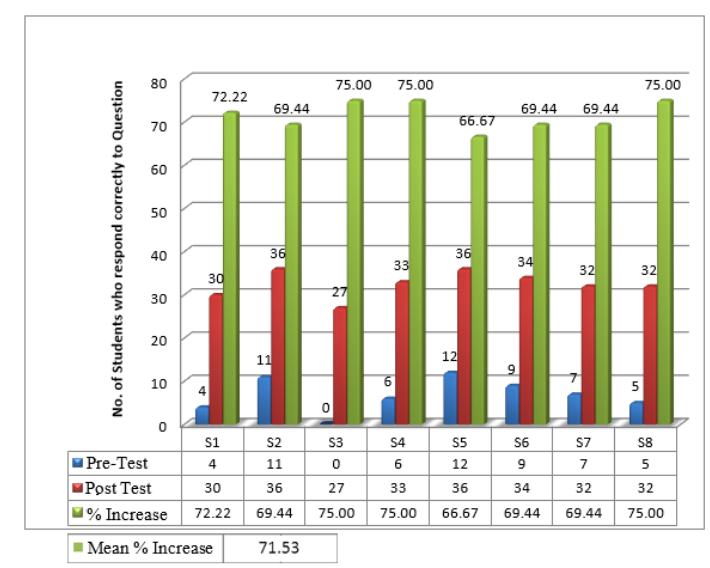

Fig. 2: Comparison of Treatment Group Achievement in Pre-Test $(\mathrm{N}=36)$ and Post-Test $(\mathrm{N}=36)$

The independent samples $t$-test was conducted to compare students' achievement before the intervention was implemented. There was a non-significant difference in the scores for the control group $(M=2.2, S D=0.81)$ and treatment group $(M=1.9, S D=0.62) ; t(70)=1.63, p=.107$. Meanwhile, after the intervention, the result revealed that there was a significant difference in the scores for the control group $(M=2.7, S D=1.20)$ and treatment group $(M=7.2, S D=0.72) ; t(70)=-19.11, p<.001$.

\section{Discussion on Student Mathematical Achievement}

Based on Fig. 1 and 2, this study found that the mean percentage $(\%)$ increase in the correct answered of the control group was $7.29 \%$, while the mean percentage (\%) increase in correct answered by the treatment group was $71.53 \%$. However, the difference is not significant in pretest. These results were also supported by the independent sample $t$-test. These results demonstrated that students were at the same level of intelligence. This finding is congruous with the findings of [26], which stated that the mean score obtained in the control group and the treatment group for pre-test are insignificant as both groups responded to questions given based on existing knowledge. It can be concluded that the students of the control group and treatment group had similar knowledge and experience when answering the given questions. It is supported by [27], through their finding that both groups had acquired the same mean score for pre-test even when treatment groups obtained higher mean scores. This proves that both groups are balanced in terms of achievement and competence.

Meanwhile, the findings showed that there are significant differences of mean score between the control group and the treatment group in the post test experiment. This is supported by [25], which found that the mean of treatment 
group was higher than the control group. The mean score for the post-treatment test far exceeds the mean of the post-test score for the control group. This clearly demonstrates the effectiveness of using the Smart Kit on student achievement in Measurement and Geometry topics as compare with the conventional method. This finding is in line with the findings by [28], which stated that ICT-based teaching is aimed at increasing the achievement of teaching. They found that the utilization of ICT in the classroom sanctions the students to cerebrate at a higher level and not just solely memorize the facts given.

The above findings showed the effectiveness of Smart Kit in enhancing students' mathematical achievement. This finding is congruous with the findings of [29], which stated that the mastery of pedagogical skills and the engagement of hands-on activities is the most effective learning strategy.

\section{CONCLUSION}

The use of the developed Smart Kit in TaL can potentially enhanced students' problem solving, reasoning and connecting skills of the mathematical process skills. The use of the developed Smart Kit engenders creative thinking among students in making connections of ideas in mathematics. Its utilization additionally sanctions the students to respond to every question provided by the teacher expeditiously and accurately.

Thus, the effectiveness of the Smart Kit in enhancing students' mathematical process skills is expected to have a positive impact and help in producing students that appreciate the beauty of mathematics and learn mathematics meaningfully. This is because meaningful mathematical learning which accentuation on the skills of mathematical processes can strengthen the underlying mathematical concepts and these concepts can be applied to higher education levels [16], [30].

In conclusion, the use of the developed Smart Kit in the teaching of mathematics can enhance mathematical process skills and hence improved the achievement among students in primary school.

\section{ACKNOWLEDGMENT}

The researchers would like to acknowledge Universiti Pendidikan Sultan Idris (UPSI), Malaysia for the financial funding of this research. Grant no.2018-0049-107-01.

\section{REFERENCES}

1. J. K. Coates, and H. P. Wilson, "Learning while playing: Children's Forest School experiences in the UK," British Educational Research Journal, 45(1), 2019, pp. 21-40.

2. M. Dockendorff, and H.Solar, "ICT integration in mathematics initial teacher training and its impact on visualization: The case of GeoGebra," International Journal of Mathematical Education in Science and Technology, 49(1), 2018, pp. 66-84.

3. E. Pujiastuti, and Mashuri, "Making a math teaching aids of junior high school based on scientific approach through an integrated and sustainable training," Journal of Physics: Conference Series, 824(1), 2017, pp. 1-6.

4. S. Fuentemilla, and J. Domínguez, "How to create a STEAM installation," ACM International Conference Proceeding Series, 2018, pp. 118-119.
5. E. O. Bereczki, and A. Kárpáti, "Teachers' beliefs about creativity and its nurture: A systematic review of the recent research literature," Educational Research Review, 23, 2018, pp. $25-56$.

6. J. Xiang, and T. B. Jin, "Instrumental teaching AIDS for sound and vibration education," 25th International Congress on Sound and Vibration, 2018, pp. 5100-5104.

7. Ministry of Education Malaysia, Malaysia's Education Development Plan 2013-2025. Putrajaya: Curriculum Development Division, 2012.

8. M. Kumar, I. Saxena, J. Kumar, G. Kumar, and S. Kapoor, "Assessment of lecture strategy with different teaching aids," Journal of Clinical and Diagnostic Research, 9(1), 2015, pp. CC01-CC05

9. P. D. Martino, and F. Gregorio, "The mathematical crisis in secondary-tertiary transition," International Journal of Science and Mathematics Education, 17(4), 2019, pp. 825843.

10. D. Fouryza, S. M. Amin, and R. Ekawati, "Review of learning materials development procedure based on fun and easy math (FEM)," AIP Conference Proceedings, 2014(1), 2018, pp. 1-9.

11. G. A. Nortvedt, and A. Siqueland, "Are beginning calculus and engineering students adequately prepared for higher education? An assessment of students' basic mathematical knowledge," International Journal of Mathematical Education in Science and Technology, 50(3), 2019, pp. 325-343.

12. K. Higgins, J. H. D. Angelo, and L. Crawford, "Effects of technology in mathematics on achievement, motivation, and attitude: A meta-analysis," Journal of Educational Computing Research, 57(2), 2019, pp. 283-319.

13. P. T. Tosic, and J. Beeston, "Designing undergraduate data science curricula: A computer science perspective," ASEE Annual Conference and Exposition, Conference Proceedings, 2018, pp. 1-11.

14. T. J. Impelluso, "The moving frame method in dynamics: Reforming a curriculum and assessment," International Journal of Mechanical Engineering Education, 46(2), 2018 , pp. 158-191.

15. X. Yan, J. Mason, and G. Hanna, "Probing interactions in exploratory teaching: A case study," International Journal of Mathematical Education in Science and Technology, 50(2), 2019, pp. 244-259.

16. A. Mahmood, Y. M. Yusof, and M. F. Othman, "Integrating mathematical thinking-oriented problem-solving approach with blended learning open source science or math studies (BLOSSOMS) modules," AIP Conference Proceedings, 1750(1), 2015, pp. 1-6.

17. S. T. Yong, P. Gates, and A. T. Y. Chan, "A gaming perspective on mathematics education," International Journal of Information and Communication Technology Education, 14(4), 2018, pp. 85-98.

18. D. M. S. Diba, and S. Prabawanto, "The analysis of students' answers in solving ratio and proportion problems," Journal of Physics: Conference Series, 1157(3), 2019, pp. 1-6.

19. M. Samuelsson, and J. Samuelsson, "Proficient classroom management through focused mathematic teaching," Problems of Education in the 21st Century, 75(6), 2017, pp. 654-651.

20. M. L. Dewi, A. R. Hakim, A. Setiawan, S. Adhisuwignjo, and E. Rohadi, "Mathematics teaching aids to improve the student's abstraction on Geometry in Civil Engineering of State Polytechnic Malang," IOP Conference Series: Materials Science and Engineering, 434(1), 2018, pp. 1-5.

21. M. Anggo, and L. Arapu, "The use of mathematics teaching aids to train metacognition ability of elementary school students," Journal of Physics: Conference Series, 1028(1), 2018, pp. 1-6. 
22. E. S. Sugiman, and N. F. Kurniawati, "Growing of the mathematical thinking imaginative to students in designing of the teaching aids for CWD towards to joyful learning," Journal of Physics: Conference Series, 983(1), 2018, pp. 1-5.

23. S. Kaur, and A. Kauts, "Impact of webquest on student engagement," Indian Journal of Public Health Research and Development, 9(12), 2018, pp. 1665-1669.

24. C. Xie, M. Wang, and $\mathrm{H}$. Hu, "Effects of constructivist and transmission instructional models on mathematics achievement in mainland China: A meta-analysis," Frontiers in Psychology, 9, 2018, pp. 1-18.

25. M. Wronowski, A. Urick, A. S. P. Wilson, W. Thompson, D. Thomas, S. Wilson, F. J. Elizondo, and R. Ralston, "Effect of a serious educational game on academic and affective outcomes for statistics instruction," Journal of Educational Computing Research, 2019, 2019, pp. 1-33.

26. C. S. Fui, and L. H. Lian, "The effect of computerized feedback on students' misconceptions in algebraic expression," Pertanika Journal of Social Sciences and Humanities, 26(3), 2018, pp. 1387-1403.

27. Y. Topkaya, "The impact of instructional comics on the cognitive and affective learning about environmental problems," Egitim ve Bilim, 41(187), 2016, pp. 199-219.

28. C. Hursen, "The impact of Edmodo-assisted project-based learning applications on the inquiry skills and the academic achievement of prospective teachers," TEM Journal, 7(2), 2018, pp. 446-455.

29. M. Öztürk, "An evaluation of an innovative in-service teacher training model in Turkey," International Journal of Higher Education, 8(1), 2019, pp. 23-36.

30. F. Zulkifli, R. Z. Abidin, N. F. M. Razi, N. H. Mohammad, R. Ahmad, and A. Z. Azmi, "Evaluating quality and reliability of final exam questions for probability and statistics course using Rasch model," International Journal of Engineering and Technology (UAE), 7(4), 2018, pp. 32-36. 